\title{
TEACHING OF ETHICS IN MEDICAL UNDERGRADUATE PROGRAMS
}

\author{
Ana Carolina Alvares Lavigne de Lemos Tavares ${ }^{1}$, Ana Gabriela Alvares Travassos ${ }^{2}$, Rodrigo da Silveira \\ Tavares $^{3}$, Maria Francisca Melo Pojal da Silva Rêgo ${ }^{4}$, Rui Manuel Lopes Nunes 5
}

\begin{abstract}
Literature points to the existent diversity in medical graduate courses' curriculums, reinforcing the need to systematise and deepen more studies in this area with the aim of qualifying the formation of our future professionals. This study aims to understand the methods used in the teaching of Bioethics in medical graduation worldwide. It was characterised as an integrative review and the databases used were Pubmed, Scopus and Web of Science. In total 2993 articles were identified and 72 met the pre-selected criteria and were included in the review. The characteristics of teaching bioethics that stood out the most in the analysis were: teaching still very heterogeneous between different universities, use of various methodologies in the process of teaching/learning, teaching disconnected from the medical practice of students showing the need to integrate the curriculum with clinical practice and challenges of teaching-learning process. Most of the studies in this review lead us to understand that there is still no minimum parameters on the ideal method to teach bioethics, suggesting that it may affect the feeling of unpreparedness felt by students in face of ethical issues in clinical practice, despite the theoretical basis acquired.
\end{abstract}

Keywords: bioethics, core curriculum, medical education, medical ethics, teaching

\section{Enseñanza de la ética en programas de pregrado médico}

Resumen: La literatura apunta a la diversidad existente en los currículos de los posgrados de medicina, reforzando la necesidad de sistematizar y profundizar más estudios en esta área, con el fin de capacitar la formación de nuestros futuros profesionales. Este estudio tiene como objetivo comprender los métodos utilizados en la enseñanza de la bioética en la graduación médica en el mundo. Se caracterizó como una revisión integradora y las bases de datos utilizadas fueron Pubmed, Scopus y Web of Science. En total se identificaron 2.993 artículos, 72 cumplieron los criterios preseleccionados y se incluyeron en la revisión. Las características de la enseñanza de la bioética que más se destacaron en el análisis fueron: docencia aún muy heterogénea entre diferentes universidades, uso de diversas metodologías en el proceso de enseñanza/aprendizaje, docencia desconectada de la práctica médica de los estudiantes, mostrando la necesidad de integrar el currículo con la práctica clínica y los desafíos del proceso de enseñanza/aprendizaje. La mayoría de los estudios de esta revisión nos lleva a entender que aún no existen parámetros mínimos sobre el método ideal para enseñar bioética, sugiriendo que puede impactar en la falta de preparación que sienten los estudiantes ante cuestiones éticas en la práctica clínica, a pesar de las teorías base adquiridas.

Palabras clave: bioética, currículo básico, educación médica, ética médica, docencia

\section{Ensino da ética nos cursos de graduaçáo em medicina}

Resumo: Vários estudos relatam a diversidade existente nos currículos da graduação em medicina, reforçando a necessidade de sistematizar e aprofundar mais estudos nesta área com o objetivo de qualificar a formação dos nossos futuros profissionais. Este estudo tem como objetivo compreender os métodos utilizados no ensino da Bioética na graduaçáo em medicina em todo o mundo. Esse estudo caracterizou-se como revisão integrativa e as bases de dados utilizadas foram Pubmed, Scopus e Web of Science. No total, foram identificados 2.993 artigos e 72 atenderam aos critérios pré-selecionados e foram incluídos na revisão. As características do ensino da bioética que mais se destacaram nas análises foram: ensino ainda muito heterogêneo entre as diferentes universidades, utilização de diversas metodologias no processo de ensino / aprendizagem, ensino desvinculado da prática médica dos alunos evidenciando a necessidade de integração curricular com a prática clínica e os desafios do processo ensino-aprendizagem. A maioria dos estudos desta revisão nos leva a entender que ainda não existem parâmetros mínimos sobre o método ideal de ensino da bioética e traz como um desafio importante o despreparo sentido pelos alunos frente às questôes éticas na prática, apesar da fundamentação teórica adquirida.

Palavras-chave: bioética, currículo básico, educação médica, ética médica, ensino

\footnotetext{
${ }^{1}$ Faculty of Medicine of the University of Porto, Portugal. Department of Health Sciences of the University of Santa Cruz, Ilhéus, Brasil. ORCID: https://orcid.org/0000-0003-0651-980X

Correspondence: aclavigne@uol.com.br

${ }^{2}$ Department of Life Sciences of the State University of Bahia, Salvador, Brasil. ORCID: https://orcid.org/0000-0001-9242-828X

${ }^{3}$ Metropolitan Union of Culture and Education, Itabuna, Brasil. ORCID: https://orcid.org/0000-0003-0245-3591

${ }^{4}$ Faculty of Medicine of the University of Porto, Portugal. ORCID: https://orcid.org/0000-0001-8083-7895

${ }^{5}$ Faculty of Medicine of the University of Porto, Portugal. ORCID: https://orcid.org/0000-0002-1377-9899
} 


\section{Introduction}

The ethical training received by healthcare professionals, especially physicians, varies considerably according to academic institutions. In stark contrast to the other academic aspects of medical education, ethics has no standardized curriculum to stipulate subject matter, workload, timing, or assessment practices let alone universal minimum requirements to guide its implementation(1).

In 2008, a systematic review analysed 30 years of studies published on ethics, bioethics and deontology education in Brazilian medical schools. The authors could only find three studies published in three different decades that documented a stagnation in the number of specific subjects for medical ethics, low workload and the reduced number of teachers exclusively dedicated to the discipline. The article emphasizes the need for a consensus among those responsible for medical ethics and bioethics education regarding the process of ethics education for medical students(2). The concept of bioethics as a scientific discipline emerged in the 1970s through Van Potter's seminal writings and, within the healthcare field, it defines and defends over time the values considered essential in a pluralist, multicultural society to resolve the ethical dilemmas of daily life(3). It is also important to highlight the emergence of new medical ethics in the form of a set of major principles that guide the application of clinical practice and human-subjects research, which, as such, also serve to support the resolution of ethical conflicts. Hence the need, in modern society, for a consensus on the ethical principles fundamental at a cross-cultural level(4).

A review of ethics education in undergraduate medicine reveals profound flaws in the literature and describes encountering two main perspectives on the purpose of teaching medical ethics. The first is as a means of creating virtuous doctors while the second reflects the need to provide doctors with a set of skills to analyse and resolve the ethical dilemmas they may encounter in their practice. This dichotomy in the literature demonstrates the lack of consensus on the objectives underlying of medical ethics education(5). A European study published in 2009 addresses the importance of teaching clinical ethics to healthcare professionals and presents a multidisciplinary and pluralistic reflection on bioethics in problems affecting human beings as a result of advances in biology and medicine(6). Yet, almost a decade later, Gulino et al. (2018)(7) report that in Italy, bioethics coursework is still infrequently offered to students and is not subject to any established academic standard.

This initial analysis demonstrates the heterogeneity of teaching medical ethics and bioethics in medical graduation making it imperative to conduct more in-depth studies in this area so we can most effectively equip our future healthcare professionals with the knowledge required to be ethical medical practitioners. Given these considerations, the objective of the present study was to delineate and analyse the methods used to teach medical ethics and bioethics in medical education programs worldwide.

\section{Methods}

This integrative review study involved the following six stages. In the first stage, a theme was identified and a research hypothesis or question selected; the second stage consisted of establishing criteria for the inclusion and exclusion of studies identified by searching the literature; in the third stage, pre-selected (based on title and abstract) and selected studies (based on full text) were identified; the fourth stage required categorizing the selected studies using a synthesis matrix; in the fifth stage, the groups of thematically-related studies were analysed and the results interpreted; finally, in the sixth stage, the knowledge and insight acquired in the fifth stage were reviewed, synthesized, and herein presented $(8,9)$. The research question guiding this review was: How is bioethics education carried out in graduate medical training around the world?

Three major health databases were queried for relevant articles: Pubmed, Scopus and the Web of Science. The keywords used to filter studies based on their presence in the title and abstract were "Bioethics" and "Medical Ethics". This literature search was not delimited by a publication period to ensure the inclusion of all potentially relevant studies in the ensuing analysis. The quality and eligibility of each study were independently de- 
termined by two researchers (AT, RT). All data were extracted manually, not by extraction software. The results from all of the qualified studies were critically reviewed by three researchers (AT, AGT, RT) and two coordinators (FR, RN). Any disagreements regarding an article's relevance were resolved by reaching a consensus among the authors.

To be included in the present study, articles were required to fulfil the following criteria: written in English and Portuguese; medical school-related; relating to Curriculum and/or Medical Education. Articles that did not address medical courses/curricula specifically were excluded as were those on masters and doctoral-level programmes, articles that address healthcare areas other than medicine, letters to the editor, comments, editorials, case studies, conferences, symposia, points of view, and communications.

A total of 2,993 articles were identified. The studies were carefully analysed by title, abstract, and finally, the complete texts. This process resulted in 72 articles that met the inclusion criteria. Figure 1 illustrates the diagram of the selection process, which was performed according to the PRISMA guidelines(10).

To enable downstream analyses of the articles, data extraction tables were prepared by the authors with the following relevant information: title; journal and year of publication; authors; origin (country, city and/or region); objectives; method; instruments; sample; results and conclusions. After this initial characterization, we performed to a more in-depth reading to extract the central themes and most important conclusions of the articles. This information was extracted and summarized in three thematic categories: Methodological variations in Medical curriculum, Principle-practice disconnection in bioethics teaching and Challenges of teaching-learning process.

\section{Results}

A total of 72 studies were included in this review. Most of the analysed articles (70.1\%) had been published since 2000 . The oldest article in the sample was published in 1977 . Roughly $28.6 \%$ of the articles were published in the 1980s and 1990s. The countries that contributed the most publications on the subject were the United States (US) with $27.27 \%$ followed by the United Kingdom (UK) with $19.48 \%$. Four studies involved the participation of more than one country. Medical education-related journals were the predominant publication outlet (41.6\%) and journals dedicated to medical ethics and/or bioethics specifically were responsible for publishing $29.9 \%$ of the articles included in the present study.

Concerning methodology, $52.8 \%$ of the articles included in this review were empirical. There was a predominance of descriptive studies on the courses and curricula with $41.3 \%$ of the total, followed by $20 \%$ of studies evaluating the learning process, and $12 \%$ of studies analysing student perception (Table 1). The review and comparative studies were similarly represented with approximately $10 \%$ of the articles each, while studies involving some type of intervention comprised only $5.3 \%$ of the total sample.

The characteristics of bioethics teaching in medical education that stood out the most from the analysis were: (1) use of different methodologies in the process of teaching/learning; (2) teaching disconnected from the students' clinical experiences (3) challenges of teaching-learning process in medical courses.

The following presents an analysis of each highlighted themes.

\section{Methodological variations in medical curricu- lum}

Of the articles covered in this integrative review, $31,94 \%$ reinforce the notion that bioethics education is still quite heterogeneous, both in terms of its minimum requirement, in defining the primary objective of this course of study and in the diversity of the methodologies used to teach.

In the USA, some studies were carried out that affirmed the wide variation of ethics curricula in medical schools $(1,11,12)$ and the need to standardize the content within this discipline(5). A study published in 2015 concludes that a methodological strategy of incorporating written eth- 
ics projects and a glossary of basic concepts into the curriculum increases medical students' moral reasoning capabilities(13).

The study published jointly by American and Canadian authors in 2004(14) that explores North American medical ethics curricula also states that there is no common standard for ethics education. A 2016 study in Canada(15) also reflects the need for students to have a tailored ethics curriculum particularly within a culturally diverse group of medical students.

In Turkey, a study was conducted in 2009(16) that reports how ethics is taught in medical schools in a very diverse manner and with the increase in medical schools the need for standardization becomes more pressing(17).

Studies show that ethics are consolidated in medical curricula across the European Union and highlight a significant disparity in the characteristics of programs across schools $(18,19)$ in addition to a considerable debate over the most effective learning and teaching approaches(20).

Further evidence of the lack of clarity and uniformity in the objectives of medical ethics education is provided in a study published in 2016(21) on medical schools in English-speaking countries (mainly the UK, US and Australia) and in another published in 2017 in Saudi Arabia(22).

Four researchers $(23,26)$ compared teaching methodologies for teaching ethics, analysing the effectiveness between traditional methodologies and those considered active methodologies such as problem-based learning (PBL), team-based learning (TBL) and use of role-playing. The results showed no significant differences between the learning in the two groups.

Some studies revealed that small-group-based teaching approaches positively impact student learning(27-31), however the results still cannot confirm whether the improve cognitive performance was accompanied by a change in the students' attitudes.

\section{Principle-practice disconnection}

Most of the articles (38.8\%) included in this integrative review deal with a major difficulty often cited: the disconnection between the ethics taught in a classroom and those relevant to students' contemporary clinical practice. This discordance and its frequent mention in the literature strongly support the pressing need to integrate the curriculum.

In the 1980s, three studies were published describing the evolution of ethics education in the US(32-34) and their main conclusion was that ethics education should be applied in practice allowing for better doctor-patient decision making. The studies published by Howe (1987) (35), Bresnahan and Hunter (1989)(36) and Olick (2001)(37) stress the importance of including integrated ethics in all years of an academic medical training program, while Hart (1995)(38) supports starting ethics coursework in student's second year when students tend to emerge from innocence. Some studies propose an educational intervention that incorporates medical ethics training in the context of clinical training, which has been shown to increase confidence and clinical decision-making capacity $(39,40)$ reinforcing the need for ethics education to permeate everyday experiences(41). The influence of behaviour models on student's ethics training is highlighted in order to bridge the gap between theoretical teaching and applied practice $(42,43)$.

Two studies published in 2010, one in the US(44) and the other in Canada(45), conclude that centralizing the patients and their vulnerabilities, from the beginning of medical education, can foster a deeper integration of the various elements - bioethics and clinical sciences - in medical school curricula.

In Japan, Miyasaka et al. (1999)(46) verified that the integration in the clinical cycle of medicine graduation was very diverse. In South Africa, Moodley (2007) (47) verified that the ethics coursework taught in medical schools was inconsistent, with an existing gap between the first and fifth year of the medical graduation course. A study published jointly by the US and Canada in 2004(14) also concludes that the greatest challenge facing the field is overcoming the lack of coordination between the pre-clinical and clinical training periods. 
Several studies describe the sense of unpreparedness that learners experience when ethical issues arise in practice, even with the appropriate conceptual training, and emphasize the importance of students having role models when learning to implement their ethical training(48-52).

Puthucheary (1980)(53) analysed the curricula of medical schools in the US, Germany, the Netherlands, Australia and the UK and proposed a core curriculum integrating an ethics course for each year of the medical graduation course. A review study published in 1986(54) examines ethical education in various cultures over the past two decades and concludes that teaching ethics integrated into the clinic could improve clinical performance and personal satisfaction of students. In England, Delaney and Kean (1988)(55) examine ethics education in British colleges and emphasize the importance of teaching this unique discipline using a practical and case-oriented approach. A survey was conducted at medical schools in the UK to describe how ethics was taught in 2004(56) and the results show that the most highly rated aspects of the courses were their integrated nature and small-group-based approach.

In Saudi Arabia, Mattick (2006)(57) recommends that bioethics in the Islamic world be taught in clinical settings. In Jerusalem(58), a study conducted in 2008 further confirmed that medical ethics is an integral part of medical training and not an isolated discipline because it contributes greatly to the fundamental principles underlying medical practice. The most recent study within this group was published in 2018 in New Zealand (59) and the findings demonstrate the value of integrating pre-clinical years with the clinical ones towards instilling sound ethical clinical reasoning among medical students.

\section{Challenges of the teaching-learning process}

The following articles describe some local experiences in medical ethics education in addition to covering aspects considered as challenges by the authors.

The oldest article of this nature was published in 1977 in England(60) by a working group formed to evaluate the curriculum of a medical school and concludes that medical ethics has its place in this curriculum.

In 2010, two studies were published reviewing the first model curricula on medical ethics and law within the medical education system in the UK and conclude that the main content is consistent with the guidelines for graduate-level ethics education in addition to the important role played by the faculty $(61,62)$.

An article (63) published in 2014 presents a guide prepared by the Institute of Medical Ethics (IME) for the evaluation of ethics and medical law in medical schools in the UK. Four surveys assessed whether the recommendations offered by medical institutions were implemented in the curricula of UK-based medical schools(64-67), in which all confirmed positively. Only Brooks \& Bell (2017) warn that these data do not comprehensively reflect the current state of UK-based medical schools due to the major limitation of a low participation rate.

A study from the 1990s in India found its medical ethics programme well-suited to meet its needs(68) and in 2018, D'Souza(69) published follow-up study with a proposal for a new bioethics curriculum, namely, the horizontal and vertical curriculum of integrated bioethics, based on the basic principles outlined by the UNESCO (United Nations Educational, Scientific and Cultural Organization) curriculum.

In Brazil, the National Curricular Guidelines for Undergraduate Medical Courses include several bioethics elements(70). A study conducted in Singapore in 2011(71) concludes that pioneering the development of a formal ethics curriculum significant affected the ethical development of first-year medical students. In China, a study that examines ethics education in three medical schools concludes that the future of medical ethics education development in China was quite promising(72).

A study published in Canada in 2016(73) also describes an innovative cross-cultural course in clinical ethics that considers biomedicine, bioethics and cultural constructs with the objective of providing ample skills for effectively resolving with 
cross-cultural ethical dilemmas in clinical care.

A major challenge here illustrates the surprising lack of medical ethics education in a study carried out in Africa in 2017(74) and signals the urgent need to formally include this topic in medical school curricula to ensure that ethical practices are maintained by future students generations of health professionals.

Other authors point out as challenges the need for reflection and consequent revision of curricula to fit the needs of the modern world. A study(75) was conducted in 2014 to determine to what extent the recommendations made in the 2010 IME consensus statement had been incorporated into UK-based medical schools relative to "early life" teaching and assessment; the results showed that only two schools had a clear place for this topic in their curriculum. A study from Saudi Arabia in 2011(76) discusses how the approaches used in ethics education make teaching difficult. Moreover, in Pakistan(77) a survey revealed the need to review the undergraduate medical bioethics curriculum. Whereas in Sri Lanka in 1992(78), the inability of the traditional medical ethics program to deal with modern ethical issues was described.

Tweel (1982) focused on five doctrines based on ethical principles to improve medical training in American schools, which were considered at the time as an essential ideal to be pursued(79). Another study that also originates in the US(80) highlights the challenges associated with the hidden curriculum inherently present in medical training and demonstrates the importance of this problem and the difficulty in finding a solution.

To conclude this category, an article published in 2005 in England(81) warns of the dangers of the irresponsible use of the four-principles approach in undergraduate medical curricula, culminating in a mistaken sense of having a complete ethics module.

\section{Discussion}

This integrative review was carried out to better understand the methods used in teaching bioethics in undergraduate medical courses. The articles selected for analysis in the present study have contributed several important aspects of the development and optimization of the teachinglearning process, providing descriptions of the practices in medical schools across the globe, the most striking characteristics and pressing challenges experienced over time, some of which persist even now, that aid in the reflection of medical educators today.

The first thematic category deals with the methodological variations in medical curriculum. How ethics is currently taught differs widely and we need to weigh the positive and negative aspects of this heterogeneity. The constantly increasing cultural diversity characteristic of modern culture makes the variability between teaching methods necessary; however, medical educators must be attentive to the minimum required standards in terms of the content covered and learning objectives necessary to ensure effective ethics training. A World Health Organization bulletin stresses that since 1999, medical schools have been strongly encouraged to include medical ethics and human rights training in their curricula and that one of the greatest challenges would be developing an ethics guide that transcends social, cultural and national issues(82). In addition, the World Medical Association (WMA) (83) in 2006 and UNESCO (84) in 2008 published suggestions for basic curricula that are adaptable to different contexts; thereby reinforcing that the objective of medical ethics education is to enable students to identify ethical conflicts and act rationally towards resolving them.

Some studies point out that the methodologies proved best for the knowledge acquisition, such as teaching in small groups and TBL, are unable to measure the outcome of the formative process, which is the long-term acquisition of skills and abilities in the field of ethics capable of changing students' attitudes, also explored in other articles(85-87).

The second category highlighted was principlepractice disconnection, most of the articles that comprise this grouping explain and support the need for integration between basic classroom lessons and real-life clinical applications. Some studies point out that medical education is more effective when linked to daily practices(88), which 
justifies the notorious concern of educators about the feeling of unpreparedness among students when first dealing with conflicts that arise in healthcare practice(89-92). These studies support implementing a curriculum that contributes both to the acquisition of theoretical knowledge and practical skills, namely 'soft skills'; however, some also acknowledge that this is a very complex process $(93,94)$ with no theoretical or practical model to guide this integration(95). Curriculum integration is as delicate as it is important to educators because the intensity inherent to medical training in practice can easily turn detrimental when it occurs without proper critical reflection and guidance from role models(96).

Finally, the last category dealt with the challenges of the teaching-learning process in situations that range from the absence of the subject of ethics felt by students in Africa, to the need to adapt the bioethics curricula in some Asian countries, to the challenges in the implementation of already consolidated curricula, such as in the UK and US. There is no consensus on the objectives and best practices in teaching ethics(97), but there is an understanding that a solid knowledge of ethics is essential to sound clinical practice (95) inextricably associated with the influence of a hidden curriculum in the development of future physicians(98). The need to think about changes in the formative processes underlying healthcare courses that take into account the public health needs of populations(99) in line with the challenges of the $21^{\text {st }}$ century by drawing from the fundamental skills imparted by a comprehensive medical training is also stressed(100).

\section{Conclusions}

Trying to answer the research question of how to understand the methods used when teaching of bioethics in medical contexts, most of the studies in this review, taken together, lead to the conclusions that there is still no minimum curricular parameters about the ideal way to approach this crucial matter.

The studies published in the US best portray this aspect of the non-homogeneity of teaching and the need for standardization. Some countries, such as the UK, report that ethics coursework already occupies an established place in their curricula, in addition to investing in recent decades in adopting the recommendations agreed upon by their medical institutions. The aspects most highly recommended in some studies are the nature of the integrated curriculum and teaching in small groups.

An important aspect highlighted in the vast majority of studies is that ethics education should be applied to students' clinical practices and allowed to permeate their daily experiences. While this is undoubtedly a powerful educational element, some studies also draw attention to the challenges of a hidden curriculum that neither the institution nor the educators have control over or the capacity to measure.

One of the biggest challenges facing the field is the perception of learners, in several studies of this sample, of unpreparedness concerning ethical issues in clinical practice even with sufficient conceptual training and the importance of role models in this training process. Bioethics is still a very subjective subject with evaluation formats that do not allow the knowledge incorporated into students' attitudes to be measured. Further studies are needed to determine the relationship between the methods used to teach bioethics and the attitudes and practices of medical students, as well as the long-term outcome. And finally, the main message that remains from this review is that the study of bioethics in medical courses does not have minimum curriculum parameters in the world and this is an important need. 

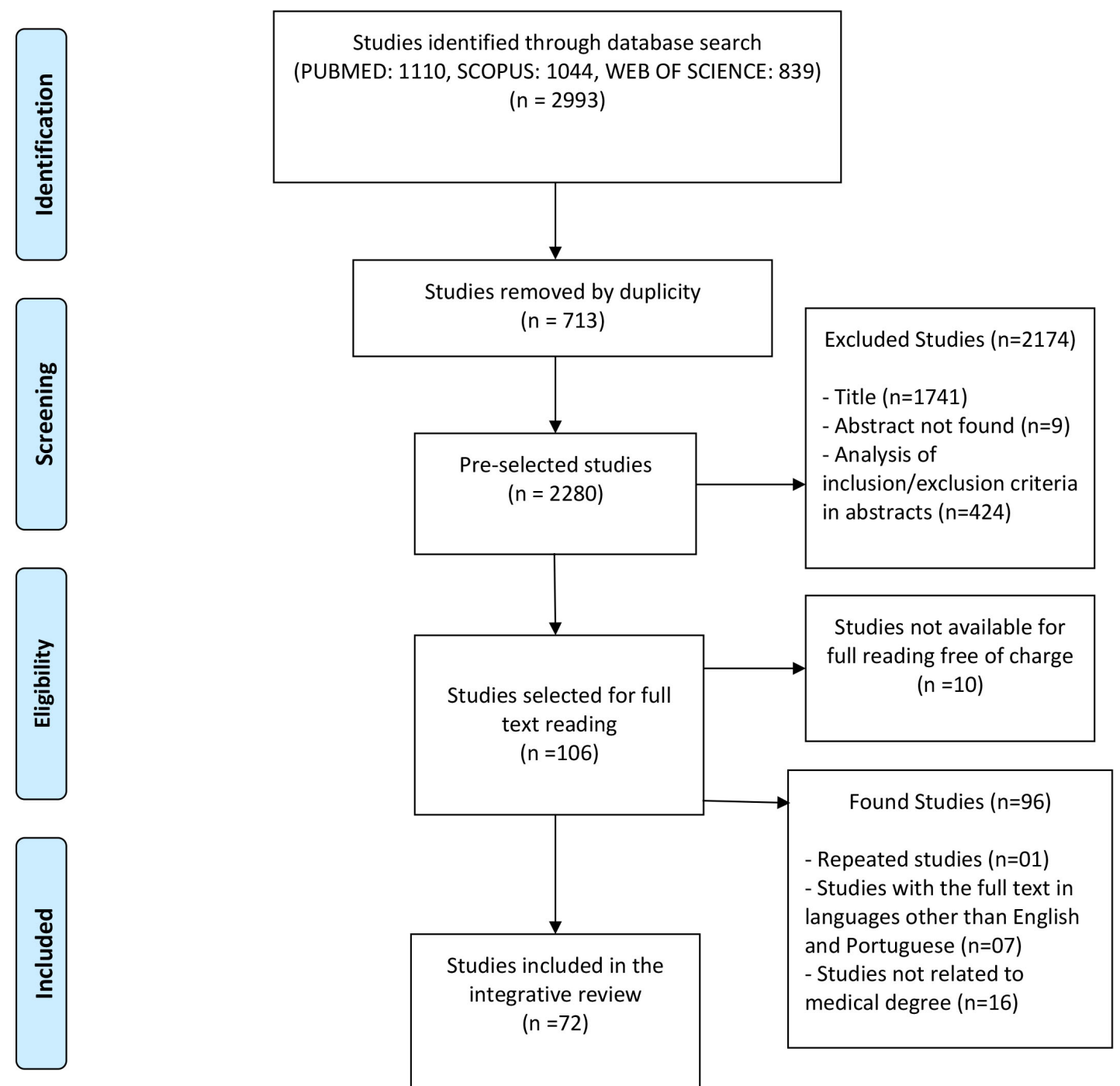

Figure 1: Diagram of the selection process of the articles according to Prisma's standards. 
Table 1. Empirical studies included in the integrative review.

\begin{tabular}{|c|c|c|}
\hline Title/ Place / year & Objectives & Methodology \\
\hline $\begin{array}{l}\text { Medical students' evaluations of different } \\
\text { levels of medical ethics teaching: } \\
\text { implications for curricula(35) } \\
\text { USA } \\
1987\end{array}$ & $\begin{array}{l}\text { To report the evaluations given by } \\
\text { clinical medical students over medical } \\
\text { ethics teaching. }\end{array}$ & $\begin{array}{l}\text {-137 preclinical and } 216 \text { clinical } \\
\text { medical students } \\
\text {-Michigan State University } \\
\text { College of Human Medicine } \\
\text { and Osteopathic Medicine }\end{array}$ \\
\hline $\begin{array}{l}\text { Attitudes of medical students to the teaching } \\
\text { of medical ethics }(55) \\
\text { UK } \\
1988\end{array}$ & $\begin{array}{l}\text { To report medical students' views on } \\
\text { teaching ethics. }\end{array}$ & $\begin{array}{l}\text { - A questionnaire was sent to } \\
\text { the first preclinical and second } \\
\text { clinical years } \\
\text { - Only } 30 \% \text { of the sample } \\
\text { responded } \\
\text { - Oxford University }\end{array}$ \\
\hline $\begin{array}{l}\text { Review of the teaching of medical ethics in } \\
\text { London medical schools }(64) \\
\text { London } \\
1990\end{array}$ & $\begin{array}{l}\text { To determine the extent and format } \\
\text { of ethics teaching in the London } \\
\text { medical schools. }\end{array}$ & $\begin{array}{l}\text {-London medical schools. } \\
\text {-Questionnaire was presented } \\
\text { to representatives of medical } \\
\text { college offices and students of } \\
\text { all London medical schools. }\end{array}$ \\
\hline $\begin{array}{l}\text { A data generated basis for medical ethics: } \\
\text { Categorizing issues experienced by Students } \\
\text { during Clinical Training }(42) \\
\text { USA } \\
1995\end{array}$ & $\begin{array}{l}\text { To use issues identified by students in } \\
\text { order to establish an experience and } \\
\text { evidence-based approach to medical } \\
\text { ethics education }\end{array}$ & $\begin{array}{l}-628 \text { sophomore and senior } \\
\text { students } \\
-249 \text { students responded } \\
\text { - State University of New York } \\
\text { at Bufallo School of Medicine } \\
\text { and Biomedical Sciences. } \\
\text {-Questionnaire }\end{array}$ \\
\hline $\begin{array}{l}\text { Changing Attitudes About End-of-Life } \\
\text { Decision Making of Medical Students } \\
\text { During Third-Year Clinical Clerkships(43) } \\
\text { USA } \\
1999\end{array}$ & $\begin{array}{l}\text { Evaluate changes in medical students' } \\
\text { attitudes about end-of-life decision } \\
\text { making. }\end{array}$ & $\begin{array}{l}\text {-96 out of } 104 \text { third-year } \\
\text { medical students } \\
\text {-Pre- and post-course survey } \\
\text {-Emory University School of } \\
\text { Medicine }\end{array}$ \\
\hline $\begin{array}{l}\text { An international survey of medical ethics } \\
\text { curricula in Asia(46) } \\
\text { Japan } \\
1999\end{array}$ & $\begin{array}{l}\text { To characterise the medical ethics } \\
\text { curricula at Asian medical schools. }\end{array}$ & $\begin{array}{l}\text { - A total of } 100 \text { medical schools } \\
\text { responded } \\
\text {-Mailed survey of } 206 \text { medical } \\
\text { schools }\end{array}$ \\
\hline $\begin{array}{l}\text { A process evaluation of medical ethics } \\
\text { education in the first year of a new medical } \\
\text { curriculum }(28) \\
\text { UK } \\
2000\end{array}$ & $\begin{array}{l}\text { To evaluate the process of medical } \\
\text { ethics education in the first year of a } \\
\text { new learner-centred, problem based, } \\
\text { integrated medical curriculum. }\end{array}$ & $\begin{array}{l}\text { - } 238 \text { students } \\
\text { - } 30 \text { clinical tutors } \\
\text { - Glasgow University's } \\
\text { - A qualitative, multi-method } \\
\text { approach } \\
\text { - Open questionnaires, focus } \\
\text { groups and tutor evaluation } \\
\text { rating scales }\end{array}$ \\
\hline $\begin{array}{l}\text { Impact of a new course on students' } \\
\text { potential behaviour on encountering ethical } \\
\text { dilemmas(29) } \\
\text { UK } \\
2001\end{array}$ & $\begin{array}{l}\text { To evaluate the effectiveness of small- } \\
\text { group ethics teaching in an integrated } \\
\text { medical curriculum. }\end{array}$ & $\begin{array}{l}\text { - A total of } 111 \text { first-year } \\
\text { students participated and a } \\
\text { control group of } 51 \text { from the } \\
\text { last year participated } \\
\text { - University of Glasgow Medical } \\
\text { School } \\
\text {-Quasi-experimental, pre- } \\
\text { and post-test, non-equivalent } \\
\text { control group design }\end{array}$ \\
\hline $\begin{array}{l}\text { Ethics Education in U.S. Medical Schools: } \\
\text { A Study of Syllabi(1) } \\
\text { USA } \\
2002\end{array}$ & $\begin{array}{l}\text { To determine the scope and content } \\
\text { of required, formal ethics components }\end{array}$ & $\begin{array}{l}-87 \text { out of } 121 \text { representatives } \\
\text { of medical schools in the U.S. } \\
\text { - Questionnaire }\end{array}$ \\
\hline
\end{tabular}




\begin{tabular}{|c|c|c|}
\hline $\begin{array}{l}\text { A Survey of Medical Ethics Education at } \\
\text { U.S. and Canadian Medical Schools(14) } \\
\text { USA / Canada } \\
2004\end{array}$ & $\begin{array}{l}\text { To explore the content, timing, } \\
\text { course format, faculty, and curricular } \\
\text { resources devoted to medical ethics }\end{array}$ & $\begin{array}{l}\text { - } 85 \text { U.S. and } 06 \text { Canadian } \\
\text { respondents } \\
\text { - Questionnaires mailed to } 125 \\
\text { U.S. medical schools and } 16 \\
\text { Canadian schools }\end{array}$ \\
\hline $\begin{array}{l}\text { Bringing Ethics Education to the Clinical } \\
\text { Years: Ward Ethics Sessions at the University } \\
\text { of Washington(39) } \\
\text { USA } \\
2006\end{array}$ & $\begin{array}{l}\text { To develop an educational } \\
\text { intervention to incorporate medical } \\
\text { ethics training as a part of students' } \\
\text { professional development within the } \\
\text { context of clinical training. }\end{array}$ & $\begin{array}{l}\text { - } 89 \text { third-year students on } \\
\text { medicine } \\
\text {-30 clinical faculty participated } \\
\text { as facilitators. } \\
\text {-Written evaluations were } \\
\text { collected from students and } \\
\text { faculty at each session }\end{array}$ \\
\hline $\begin{array}{l}\text { Medical ethics and tomorrow's physicians: } \\
\text { an aspect of coverage in the formal } \\
\text { curriculum(57) } \\
\text { Saudi Arabia } \\
2006\end{array}$ & $\begin{array}{l}\text { To review the current status of } \\
\text { bioethics teaching in medical } \\
\text { schools. }\end{array}$ & $\begin{array}{l}\text { - } 14 \text { clinical departments and } \\
201 \text { students participated } \\
\text { - College of Medicine, King } \\
\text { Faisal University Dammam, } \\
\text { Saudi Arabia } \\
\text { - Cross-sectional study }\end{array}$ \\
\hline $\begin{array}{l}\text { Undergraduate ethics teaching: revisiting } \\
\text { the Consensus Statement(65) } \\
\text { UK } \\
2006\end{array}$ & $\begin{array}{l}\text { To determine whether the } \\
\text { recommendations of the Consensus } \\
\text { Statement published } 7 \text { years ago } \\
\text { have been implemented. }\end{array}$ & $\begin{array}{l}\text { - A total of } 22 / 28(79 \%) \\
\text { medical schools completed the } \\
\text { survey } \\
\text {-Postal questionnaire survey of } \\
28 \text { UK medical schools. }\end{array}$ \\
\hline $\begin{array}{l}\text { Teaching ethics in Europe(18) } \\
\text { France } \\
2006\end{array}$ & $\begin{array}{l}\text { To carry out an appropriate overview } \\
\text { and inventory of the teaching of } \\
\text { ethics within the European Union } \\
\text { Schools of Medicine. }\end{array}$ & $\begin{array}{l}\text { - A questionnaire was sent by } \\
\text { email to } 45 \text { randomly selected } \\
\text { medical schools from each of } \\
23 \text { countries in the European } \\
\text { Union } \\
-25 \text { schools of medicine from } \\
18 \text { European countries were } \\
\text { included (response rate }=56 \% \text { ). } \\
\text { - Questionnaire }\end{array}$ \\
\hline $\begin{array}{l}\text { Teaching and assessing medical ethics: } \\
\text { where are we now?(56) } \\
\text { UK } \\
2006\end{array}$ & $\begin{array}{l}\text { To characterise UK undergraduate } \\
\text { medical ethics curricula and to } \\
\text { identify opportunities and threats to } \\
\text { teaching and learning. }\end{array}$ & $\begin{array}{l}\text { - } 14 \text { out of } 16 \text { medical schools } \\
\text { responded } \\
\text { - UK medical schools } \\
\text { - Postal questionnaire } \\
\text { - Completed responses were } \\
\text { received from } 22 / 28 \text { schools } \\
(79 \%) \text {. }\end{array}$ \\
\hline $\begin{array}{l}\text { Effects of an additional small group } \\
\text { discussion to cognitive achievement and } \\
\text { retention in basic principles of bioethics } \\
\text { teaching methods(30) } \\
\text { Indonesia } \\
2009\end{array}$ & $\begin{array}{l}\text { Investigate the effects of an } \\
\text { additional small group discussion } \\
\text { in basic principles of bioethics } \\
\text { conventional lecture methods. }\end{array}$ & $\begin{array}{l}\text {-A total of } 70 \text { participants } \\
\text {-Faculty of Medicine, University } \\
\text { of Riau, Pekanbaru. } \\
\text { - Randomized controlled trial } \\
\text { with parallel design. }\end{array}$ \\
\hline $\begin{array}{l}\text { Medical Students' Affirmation of Ethics } \\
\text { Education(40) } \\
\text { USA } \\
2009\end{array}$ & $\begin{array}{l}\text { To assess the effects of two different } \\
\text { types of research ethics training on } \\
\text { medical students' attitudes. }\end{array}$ & $\begin{array}{l}\text { - } 83 \text { out of } 300 \text { medical } \\
\text { students were invited via e-mail } \\
\text { to participate } \\
\text {-University of New Mexico } \\
\text { - Randomized, controlled } \\
\text { experiment }\end{array}$ \\
\hline $\begin{array}{l}\text { The effect of team-based learning in medical } \\
\text { ethics education(31) } \\
\text { Republic of Korea } \\
2009\end{array}$ & $\begin{array}{l}\text { Evaluated the impact of TBL } \\
\text { on student engagement and } \\
\text { satisfaction and assessed educational } \\
\text { achievements. }\end{array}$ & $\begin{array}{l}\text { - } 132 \text { ouf of the } 160 \text { first-year } \\
\text { medical students completed the } \\
\text { survey (response rate, } 79.5 \% \text { ). } \\
\text { - The } 160 \text { students were } \\
\text { assigned to } 26 \text { teams of six or } \\
\text { seven students each } \\
\text {-Chonnam National University } \\
\text { Medical School. }\end{array}$ \\
\hline
\end{tabular}




\begin{tabular}{|c|c|c|}
\hline $\begin{array}{l}\text { End-of-life ethics and disability(45) } \\
\text { Canada } \\
2010\end{array}$ & $\begin{array}{l}\text { To explore ways of teaching bioethical } \\
\text { issues to first year medical students. }\end{array}$ & $\begin{array}{l}\text { - } 6 \text { Medical students, } 4 \\
\text { Community resource speakers } \\
\text { and } 5 \text { External faculty members } \\
\text { were interviewed } \\
-9 \text { medical students, } 5 \text { Faculty } \\
\text { members and } 6 \text { External faculty } \\
\text { members participated in the } \\
\text { focus group } \\
\text { - University of Manitoba } \\
\text {-Multiple qualitative methods } \\
\text { - Participant observation }\end{array}$ \\
\hline $\begin{array}{l}\text { Interns Perceptions on Medical Ethics } \\
\text { Education and Ethical Issues at the Dokuz } \\
\text { Eylul University School of Medicine in } \\
\text { Turkey(49) } \\
\text { Turkey } \\
2010\end{array}$ & $\begin{array}{l}\text { To investigate interns' perceptions of } \\
\text { medical ethics education and ethical } \\
\text { issues. }\end{array}$ & $\begin{array}{l}\text { - } 80 \text { of the } 119 \text { interns at the } \\
\text { clinics }(67.2 \%) \text { responded } \\
\text { - Dokuz Eylul University } \\
\text { School of Medicine } \\
\text { - Questionnaire }\end{array}$ \\
\hline $\begin{array}{l}\text { Evaluating the Effects of an Integrated } \\
\text { Medical Ethics Curriculum on First-year } \\
\text { Students(71) } \\
\text { Singapore } \\
2011\end{array}$ & $\begin{array}{l}\text { Analyses the effects of the new } \\
\text { curriculum on first-year students } \\
\text { knowledge, confidence and opinions } \\
\text { in relation to the subject. }\end{array}$ & $\begin{array}{l}\text { - A group of first-year students } \\
\text { - Experimental group }(\mathrm{n}=119) \\
\text { - Control group }(\mathrm{n}=164) \\
\text { - National University of } \\
\text { Singapore Yong Loo Lin School } \\
\text { of Medicine } \\
\text { - Cohort-based quasi- } \\
\text { experimental } \\
\text { - Pre-course and post-course } \\
\text { questionnaire }\end{array}$ \\
\hline $\begin{array}{l}\text { Teaching of Medical Ethics: Students' } \\
\text { perception in different periods of the } \\
\text { course(51) } \\
\text { Brasil } \\
2011\end{array}$ & $\begin{array}{l}\text { To identify the perception of medical } \\
\text { students about ethical conflicts } \\
\text { during their academic practice, in two } \\
\text { different periods of the course }\end{array}$ & $\begin{array}{l}\text { - } 110 \text { student responded the } \\
\text { questionnaires }(71.4 \%) \\
\text { - Medical School of Federal } \\
\text { University of Sergipe (UFS), } \\
\text { - Cross-sectional study }\end{array}$ \\
\hline $\begin{array}{l}\text { Reform in medical ethics curriculum: a } \\
\text { step by step approach based on available } \\
\text { resources(27) } \\
\text { Iran } \\
2011\end{array}$ & $\begin{array}{l}\text { To revise the medical ethics } \\
\text { curriculum at the School of Medicine }\end{array}$ & $\begin{array}{l}\text { - A total of } 113 \text { were returned } \\
\text { (response rate of } 82.5 \% \text { ). } \\
\text { - Tehran University of Medical } \\
\text { Sciences } \\
\text { - Questionnaire }\end{array}$ \\
\hline $\begin{array}{l}\text { Use of role play in undergraduate teaching } \\
\text { of ethics - an experience }(26) \\
\text { India } \\
2012\end{array}$ & $\begin{array}{l}\text { Try to assess the dramatization in } \\
\text { relation to the lecture by analysing } \\
\text { student feedback. }\end{array}$ & $\begin{array}{l}\text { - } 96 \text { students of } 2 \text { nd year } \\
\text { MBBS. } \\
\text { - All the students actively } \\
\text { participated in the group } \\
\text { activity }\end{array}$ \\
\hline $\begin{array}{l}\text { Meaning and value in medical school } \\
\text { curricula(101) } \\
\text { Australia } \\
2012\end{array}$ & $\begin{array}{l}\text { Identify ethical and professional } \\
\text { concerns comparing ethics curricula } \\
\text { with themes that emerged from } \\
\text { a qualitative study of medical } \\
\text { practitioners. }\end{array}$ & $\begin{array}{l}\text { Consisted of two components: } \\
\text {-Curriculum analysis: } 32 \\
\text { curricula identified through a } \\
\text { database search } \\
\text {-Qualitative study: semi- } \\
\text { structured interviews were } \\
\text { conducted with } 20 \text { medical } \\
\text { practitioners }\end{array}$ \\
\hline $\begin{array}{l}\text { Ethics teaching on 'Beginning of Life' issues } \\
\text { in UK medical schools(75) } \\
\text { UK } \\
2013\end{array}$ & $\begin{array}{l}\text { To audit the extent to which the } \\
\text { recommendations made in the } 2010 \\
\text { IME consensus statement regarding } \\
\text { the teaching of 'Beginning of Life' } \\
\text { issues are being met in UK medical } \\
\text { schools. }\end{array}$ & $\begin{array}{l}\text { - } 21 \text { out of all } 32 \text { undergraduate } \\
\text { medical schools in the UK } \\
\text { responded } \\
\text { - Web-based questionnaire }\end{array}$ \\
\hline
\end{tabular}




\begin{tabular}{|c|c|c|}
\hline $\begin{array}{l}\text { Teaching medical ethics: problem-based } \\
\text { learning or small group discussion?(24) } \\
\text { Iran } \\
2013\end{array}$ & $\begin{array}{l}\text { To compare PBL and SGD methods } \\
\text { in teaching medical ethics. }\end{array}$ & $\begin{array}{l}\text { - Twenty students were } \\
\text { randomly assigned into two } \\
\text { groups } \\
\text { - Qom University of Medical } \\
\text { Sciences }\end{array}$ \\
\hline $\begin{array}{l}\text { Teaching and evaluation methods of medical } \\
\text { ethics in the Saudi public medical colleges: } \\
\text { cross-sectional questionnaire study(102) } \\
\text { Saudi Arabia } \\
2013\end{array}$ & $\begin{array}{l}\text { Studying the current teaching } \\
\text { methods and evaluation tools used by } \\
\text { the Saudi public medical schools. }\end{array}$ & $\begin{array}{l}\text { - Saudi public medical schools } \\
\text { - ross sectional study } \\
\text {-Self-administered online } \\
\text { questionnaire }\end{array}$ \\
\hline $\begin{array}{l}\text { How medical students learn ethics: an } \\
\text { online log of their learning experiences }(66) \\
\text { London } \\
2015\end{array}$ & $\begin{array}{l}\text { To determine the totality of the } \\
\text { medical students' learning of ethics } \\
\text { and law. }\end{array}$ & $\begin{array}{l}\text { - King's College London School } \\
\text { of Medicine } \\
\text { - Number of participants: } 99 \\
\text { - Cohort size: } 2164 \\
\text { - Percentage of group (\%): } \\
4,57 \%\end{array}$ \\
\hline $\begin{array}{l}\text { Ethics competences in the undergraduate } \\
\text { medical education curriculum: the Spanish } \\
\text { experience(19) } \\
\text { Spain } \\
2016\end{array}$ & $\begin{array}{l}\text { To investigate if there are differences } \\
\text { in medical ethics education between } \\
\text { different schools of medicine in Spain. }\end{array}$ & $\begin{array}{l}\text {-2569 subjects belonging to } 44 \\
\text { medical schools in Spain } \\
\text {-Observational, descriptive- } \\
\text { comparative, and transverse }\end{array}$ \\
\hline $\begin{array}{l}\text { Developing a bioethics curriculum for } \\
\text { medical students from divergent geopolitical } \\
\text { regions(15) } \\
\text { Canada } \\
2016\end{array}$ & $\begin{array}{l}\text { To determine the content and format } \\
\text { of an ideal bioethics' curriculum for a } \\
\text { culturally. }\end{array}$ & $\begin{array}{l}\text { - } 10 \text { students } \\
\text {-The } 2013 \text { IPEME student } \\
\text { cohort was approached and } \\
\text { asked to participate in an } \\
\text { individual, semi-structured } \\
\text { interview } \\
\text { - Qualitative study } \\
\text { - Interview }\end{array}$ \\
\hline $\begin{array}{l}\text { Medical Ethics Education in China: Lessons } \\
\text { from Three Schools(72) } \\
\text { China } \\
2017\end{array}$ & $\begin{array}{l}\text { Examined ethics education at } \\
\text { three medical schools in China to } \\
\text { understand their curricular content, } \\
\text { teaching and learning methods, forms } \\
\text { of assessments, changes over time, and } \\
\text { what changes are needed for further } \\
\text { improvement. }\end{array}$ & $\begin{array}{l}\text { - Altogether, } 232 \text { out of } 404 \\
\text { GMU students, } 99 \text { out of } 200 \\
\text { PKU students, and } 76 \text { out of } \\
270 \text { WU students responded to } \\
\text { the survey } \\
\text {-Faculty members that } \\
\text { answered the survey: } 0 \text { out of } 4 \\
\text { of the GMU, } 2 \text { out of } 4 \text { of PKU } \\
\text { and } 7 \text { out of } 14 \text { of WU } \\
\text {-Wuhan University School of } \\
\text { Medicine (WU), Guangzhou } \\
\text { Medical University GMU, and } \\
\text { Peking University School of } \\
\text { Medicine (PKU) } \\
\text { - Survey }\end{array}$ \\
\hline $\begin{array}{l}\text { Ethics teaching in a medical education } \\
\text { environment: preferences for diversity of } \\
\text { learning and assessment methods( } 52) \\
\text { United Arab Emirates } \\
2017\end{array}$ & $\begin{array}{l}\text { To examine medical students' } \\
\text { perceptions toward ethics and } \\
\text { professionalism teaching, and its } \\
\text { learning and assessment methods. }\end{array}$ & $\begin{array}{l}\text { - A total of } 108 \text { out of } 128 \\
\text { students participated. } \\
\text { - United Arab Emirates } \\
\text { University } \\
\text { - S e l f - a d m i n i s t e r e d } \\
\text { questionnaire }\end{array}$ \\
\hline $\begin{array}{l}\text { Teaching, learning and assessment of medical } \\
\text { ethics at the UK medical schools(67) } \\
\text { UK } \\
2017\end{array}$ & $\begin{array}{l}\text { To evaluate the UK undergraduate } \\
\text { medical ethics curricula against the } \\
\text { Institute of Medical Ethics (IME) } \\
\text { recommendations. }\end{array}$ & $\begin{array}{l}\text { - Completed responses were } \\
\text { received from } 11 / 33 \text { schools } \\
(33 \%) \text {. } \\
\text { - Questionnaire survey of the } \\
\text { UK medical schools }\end{array}$ \\
\hline
\end{tabular}




\begin{tabular}{|c|c|c|}
\hline $\begin{array}{l}\text { Must we remain blind to undergraduate } \\
\text { medical ethics education in Africa? A } \\
\text { cross-sectional study of Nigerian medical } \\
\text { students( } 74 \text { ) } \\
\text { Nigeria } \\
2017\end{array}$ & $\begin{array}{l}\text { To determine the views of Nigerian } \\
\text { medical students on medical ethics } \\
\text { education and medico- ethical } \\
\text { issues related to the doctor-patient } \\
\text { relationship, as well as the ethical/ } \\
\text { professional dilemmas with which } \\
\text { they may be confronted. }\end{array}$ & $\begin{array}{l}\text { - The sample included } 100 \\
\text { males }(71.4 \%) \text { and } 40 \text { females } \\
(28.6 \%) \text { - final year medical } \\
\text { students } \\
\text { - University of Nigeria } \\
\text { - Cross-sectional survey } \\
\text {-Self-administered structured } \\
\text { questionnaires }\end{array}$ \\
\hline $\begin{array}{l}\text { Preclinical Students' Views On Medical } \\
\text { Ethics Education: A Focus Group Study In } \\
\text { Turkey(50) } \\
\text { Turkey } \\
2018\end{array}$ & $\begin{array}{l}\text { To receive the opinions of the } \\
\text { preclinical medical students on } \\
\text { medical ethics education. }\end{array}$ & $\begin{array}{l}\text { - the sample consisted of } 18 \text { out } \\
\text { of } 21 \text { students } \\
\text {-Qualitative research method } \\
\text { - Focus group interviews }\end{array}$ \\
\hline $\begin{array}{l}\text { Moving Beyond the Theoretical: Medical } \\
\text { Students' Desire for Practical, Role-Specific } \\
\text { Ethics Training(48) } \\
\text { USA } \\
2018\end{array}$ & $\begin{array}{l}\text { To discover, from the students' } \\
\text { perspective, how ethics pedagogy } \\
\text { prepares medical students for clerkship } \\
\text { and what gaps might remain. }\end{array}$ & $\begin{array}{l}\text { - Three focus groups }(n=5 \text {, } \\
3,5) \text { of third- and fourth-year } \\
\text { medical students } \\
\text {-University of Pennsylvania. } \\
\text { - Pilot study } \\
\text { - Qualitative study }\end{array}$ \\
\hline $\begin{array}{l}\text { Comparison of lecture and team-based } \\
\text { learning in medical ethics education(25) } \\
\text { Turkey } \\
2019\end{array}$ & $\begin{array}{l}\text { To compare the lecture-based class } \\
\text { and TBL method. }\end{array}$ & $\begin{array}{l}\text { - } 163 \text { out of } 188 \text { students } \\
\text { participated in both of the TBL } \\
\text { and lectures during four cycles } \\
\text { in 2013-2014 academic year. } \\
\text { - Prospective controlled follow- } \\
\text { up study } \\
\text { - Instruments: In-class } \\
\text { engagement measure; } \\
\text { Observation process; Feedback } \\
\text { forms }\end{array}$ \\
\hline
\end{tabular}

\section{List of Abbreviations}

- $\quad$ USA (United States of America)

- $\quad$ UK (United Kingdom)

- $\quad$ PBL (Problem Based Learning)

- $\quad$ TBL (Team Based Learning)

- $\quad$ IME (Institute of Medical Ethics)

- UNESCO (United Nations Educational, Scientific and Cultural Organization)

\section{Declarations}

- Ethics approval and consent to participate - Not applicable

- Consent for publication - Not applicable

- Availability of data and materials - Not applicable

- Competing interests - The authors declare that they have no competing interests

- $\quad$ Funding - Not applicable

\section{Authors' contributions}

- ACALLT - participated in the elaboration of the project, study design, data collection and analysis, article writing.

- $\quad$ AGAT - participated in the study design, orientation of the data analysis, review of the writing of the article.

- $\quad$ RST - participated in the study design, data collection and analysis, review of the writing of the article.

- MFMPSR - participated in the definition of the study design, orientation of the data analysis, review of the writing of the article.

- $\quad$ RMLN - research advisor, participated in the elaboration of the project, study design, project review and the writing of the article.

- Declaration: All authors have read and approved the manuscript

\section{Acknowledgements}

Special thanks to João Carlos Lavigne de Lemos Tavares for the translations and final adjustments to the text. 
Teaching of ethics in medical undergraduate programs - Ana Carolina Alvares Lavigne de Lemos Tavares et al.

\section{References}

1. Dubois JM, Burkemper J. Ethics Education in U.S. Medical Schools: A Study of Syllabi. Academic Medicine 2002; 432-437.

2. Dantas F, Sousa EG de. The Teaching of Deontology, Medical Ethics and Bioethics in Brazilian Medical Schools: a Systematic Review. Revista Brasileira de Educação Médica 2008; 32(4): 507-517.

3. Nunes R. Bioethics: Medical. Dordrecht: Springer Science+Business Media; 2014.

4. Nunes R. Ensaios em bioética [Internet]. 2017. 200 p. Available from: http://www.flip3d.com.br/web/pub/cfm/index6 /?numero=18\&edicao=3980\#page/ 1

5. Eckles RE, Meslin EM, Gaffney M, Helft PR. Medical ethics education: Where are we? Where should we be going? A review. Academic Medicine 2005; 80(12): 1143-1152.

6. Council of Europe Publishing. Bioethical Issues. Vol. 272, Science; 2009.

7. Gulino M, Patuzzo S, Baldelli I, Gazzaniga V, Merlo DF, Maiorana L, et al. Bioethics in italian medical and healthcare education. A pilot study. Acta Biomédica 2018; 89(4): 519-31.

8. Mendes KDS, Silveira RC de CP, Galvão CM. Revisão integrativa: método de pesquisa para a incorporação de evidências na saúde e na enfermagem. Texto \& Contexto - Enfermagem 2008; 17(4): 758-764.

9. Botelho LLR, Cunha CC de A, Macedo M. O Método Da Revisão Integrativa Nos Estudos Organizacionais. Gestão e Sociedade 2011; 5(11): 121-136.

10. Galvão TF, Pansani TSA HD. Principais itens para relatar Revisões sistemáticas e Meta-análises: A recomendação PRISMA. Epidemiologia e Serviços de Saúde 2015; 24(2): 335-342.

11. Lewin LO, Olson CA, Goodman KW, Kokotailo PK. UME-21 and Teaching Ethics: A Step in the Right Direction. Family Medicine 2004; 36(SUPPL.): 36-42.

12. Musick DW. Teaching medical ethics: a review of the literature from North American medical schools with emphasis on education. Medicine, health care, and philosophy 1999; 2(3): 239-254.

13. Cummins PJ, Mendis KJ, Fallar R, Favia A, Frank L, Plunkett C, et al. Improving third-year medical students' competency in clinical moral reasoning: Two interventions. AJOB Empirical Bioethics [Internet] 2015; 7(3): 140-148. DOI: http://dx.doi.org/10.1080/23294515.2015.1065931

14. Lehmann LS, Kasoff WS, Koch P, Federman DD. A survey of medical ethics education at U.S. and Canadian medical schools. Academic Medicine 2004; 79(7): 682-689.

15. Greenberg RA, Kim C, Stolte H, Hellmann J, Shaul RZ, Valani R, et al. Developing a bioethics curriculum for medical students from divergent geo-political regions. BMC Medical Education [Internet] 2016; 16(1): 1-6. DOI: http://dx.doi. org/10.1186/s12909-016-0711-4

16. Öztürk Türkmen H. Medical ethics education and the Turkish experience: Medical education. Turkiye Klinikleri Journal of Medical Sciences 2009; 29(1): 246-253.

17. Ekmekçi PE. Medical Ethics Education in Turkey; State of Play and Challenges. International online journal of education \& teaching [Internet] 2017; 3(1): 54-63. Available from: http://www.ncbi.nlm.nih.gov/pubmed/27213100\%0Ahttp:// www.pubmedcentral.nih.gov/articlerender.fcgi?artid=PMC4871155

18. Claudot F, Alla F, Ducrocq X, Coudane H. Teaching ethics in europe. Journal of Medical Ethics 2007; 33(8): $491-495$.

19. Ferreira-Padilla G, Ferrández-Antón T, Lolas-Stepke F, Almeida-Cabrera R, Brunet J, Bosch-Barrera J. Ethics competences in the undergraduate medical education curriculum: the Spanish experience. Croatian Medical Journal 2016; 57(5): 493-503.

20. Goldie J. Review of ethics curricula in undergraduate medical education. Medical Education 2000; 34(2): 108-119.

21. Giubilini A, Milnes S, Savulescu J. The Medical Ethics Curriculum in Medical Schools: Present and Future. The Journal of clinical ethics 2016; 27(2): 129-145.

22. El Tarhouny SA, Mansour TM, Wassif GA, Desouky MK. Teaching bioethics for undergraduate medical students. Biomedical Research (India) 2017; 28(22): 9840-9844.

23. Harasym PH, Tsai TC, Munshi FM. Is problem-based learning an ideal format for developing ethical decision skills? Kaohsiung Journal of Medical Sciences [Internet] 2013; 29(10): 523-529. DOI: http://dx.doi.org/10.1016/j. kjms.2013.05.005

24. Heidari A, Adeli S, Taziki S, Akbari V, Ghadir M-R, Moosavi-Movahhed S-M, et al. Teaching medical ethics: problembased learning or small group discussion? Journal of Medical Ethics and History of Medicine 2013; 6(1).

25. Ozgonul L, Alimoglu MK. Comparison of lecture and team-based learning in medical ethics education. Nursing Ethics 2019; 26(3): 903-913.

26. Noone PH, Raj Sharma S, Khan F, Raviraj KG, Shobhana SS. Use of role play in undergraduate teaching of ethics-An 
experience. Journal of Forensic and Legal Medicine [Internet] 2013; 20(3): 136-138. DOI: http://dx.doi.org/10.1016/j. jflm.2012.06.010

27. Asghari F, Mirzazadeh A, Samadi A, Safa AN, Jafarian A, Farahani AV, et al. Reform in medical ethics curriculum: A step by step approach based on available resources. Journal of Medical Ethics and History of Medicine 2011; 4: 8.

28. Goldie J, Schwartz L, Morrison J. A process evaluation of medical ethics education in the first year of a new medical curriculum. Medical Education 2000; 34(6): 468-473.

29. Goldie J, Schwartz L, McConnachie A, Morrison J. Impact of a new course on students' potential behaviour on encountering ethical dilemmas. Medical Education 2001; 35(3): 295-302.

30. Afandi D, Budiningsih Y, Safitry O, Purwadianto A, Novitasari D, Widjaja IR. Effects of an additional small group discussion to cognitive achievement and retention in basic principles of bioethics teaching methods. Medical Journal of Indonesia 2009; 18(1): 48-52.

31. Chung EK, Rhee JA, Baik YH, Oh-Sun A. The effect of team-based learning in medical ethics education. Medical Teacher 2009; 31(11): 1013-1017.

32. Loewy EH. Teaching medical ethics to medical students. Journal of Medical Education 1986: 661-665.

33. Walker RM, Lane L, Siegler M. Development of a teaching program in Clinical Medical Ethics at the University of Chicago. Academic Medicine 1989: 723-729.

34. Jonsen AR. Medical ethics Teaching Programs at the University of California, San Francisco, and the University of Washington. Academic Medicine 1989: 718-722.

35. Howe KR. Medical students' evaluations of different levels of medical ethics teaching: implications for curricula. Medical Education 1987; 21(4): 340-349.

36. Bresnahan JF, Hunter KM. Ethics education at Northwestern University Medical School. Academic Medicine 1989: 740-743.

37. Olick RS. It's ethical, but is it legal? Teaching ethics and law in the medical school curriculum. Anatomical Record 2001; 265(1): 5-9.

38. Hart CW. From Innocence to Experience: Teaching Medical Ethics to Medical Students. Journal of Religion and Health 1995; 34(1): 55-60.

39. Fryer-Edwards K, Wilkins MD, Baernstein A, Braddock $\mathrm{CH}$. Bringing ethics education to the Clinical Years: Ward ethics sessions at the University of Washington. Academic Medicine 2006; 81(7): 626-631.

40. Lehrmann JA, Hoop J, Hammond KG, Roberts LW. Medical students' affirmation of ethics education. Academic Psychiatry 2009; 33(6): 470-477.

41. Fox E, Arnold RM, Brody B. Medical ethics education: Past, present, and future. Academic Medicine 1995; 70(9): 761 768.

42. Bissonette R, O’Shea RM, Horwitz M, Routé CF. A data generated basis for medical ethics: Categorizing issues experienced by Students during Clinical Training. Academic Medicine 1995; 70(11): 1035-1037. DOI: 10.1097/00001888199511000-00023

43. Hayes RP, Stoudemire AS, Kinlaw K, Dell ML, Loomis A. Changing attitudes about end-of-life decision making of medical students during third-year clinical clerkships. Psychosomatics 1999; 40(3): 205-211.

44. Lovy A, Paskhover B, Trachtman H. Teaching bioethics: The tale of a "soft" science in a hard world. Teaching and Learning in Medicine 2010; 22(4): 319-322.

45. Kaufert J, Wiebe R, Schwartz K, Labine L, Lutfiyya ZM, Pearse C. End-of-life ethics and disability: differing perspectives on case-based teaching. Medicine, health care, and philosophy 2010; 13(2): 115-126.

46. Miyasaka M, Akabayashi A, Kai I, Ohi G. An international survey of medical ethics curricula in Asia. Journal of Medical Ethics 1999; 25(6): 514-521.

47. Moodley K. Teaching medical ethics to undergraduate students in post-apartheid South Africa, 2003-2006. Journal of Medical Ethics 2007; 33(11): 673-677.

48. Stites SD, Clapp J, Gallagher S, Fiester A. Moving beyond the theoretical: Medical students' desire for practical, rolespecific ethics training. AJOB Empirical Bioethics [Internet] 2018; 9(3): 154-163. DOI: https://doi.org/10.1080/2329 4515.2018.1472149

49. Ozan S, Timbil S, Semin S, Musal B. Interns' perceptions on medical ethics education and ethical issues at the Dokuz Eylul University School of Medicine in Turkey. Education for Health: Change in Learning and Practice 2010; 23(3): 1-11.

50. Bilgin AC, Timbil S, Guvercin CH, Ozan S, Semin S. Preclinical Students' views on Medical Ethics Education: a focus group study in Turkey. Acta Bioethica 2018; 24(1): 105-115.

51. Pimentel D, Barbosa de Oliveira C, Vieira MJ. Teaching of Medical Ethics: Students' perception in different periods of the course. Revista Médica de Chile 2011; 139(1): 36-44. 
Teaching of ethics in medical undergraduate programs - Ana Carolina Alvares Lavigne de Lemos Tavares et al.

52. AlMahmoud T, Jawad Hashim M, Elzubeir MA, Branicki F. Ethics teaching in a medical education environment: preferences for diversity of learning and assessment methods. Medical Education Online [Internet] 2017; 22(1): 1328257. DOI: https://doi.org/10.1080/10872981.2017.1328257

53. Puthucheary SD. A curriculum in medical ethics and medical humanities. Medical Journal of Malaysia 1980; 35(1): 86-95.

54. Ewan C. Teaching Ethics in Medical School. Medical Teacher 1986; 8(2): 103-110.

55. Delaney B, Kean L. Attitudes of medical students to the teaching of medical ethics. Medical Education 1988; 22(1): 8-10.

56. Mattick K, Bligh J. Teaching and assessing medical ethics: Where are we now? Journal of Medical Ethics 2006; 32(3): 181-185.

57. Umran Al-Umran K, Al-Shaikh BA, Al-Awary BH, Al-Rubaish AM, Al-Muhanna FA. Medical ethics and tomorrow's physicians: an aspect of coverage in the formal curriculum. Medical Teacher 2006; 28(2): 182-184.

58. Gesundheit B, Shaham D. A Syllabus for Jewish Medical Ethics in the Context of General Bioethics. IMAJ 2008; 10: 397-400.

59. McMillan J, Malpas P, Walker S, Jonas M. Ethics Education in New Zealand Medical Schools. Cambridge Quarterly of Healthcare Ethics 2018; 27(3): 470-473.

60. Dennis KJ, Hall MRP. The teaching of medical ethics. Journal of medical ethics 1977; 3(1): 183-185.

61. Stirrat GM, Johnston C, Gillon R, Boyd K. Medical ethics and law for doctors of tomorrow: The 1998 Consensus Statement updated. Journal of Medical Ethics 2010; 36(1): 55-60.

62. Stirrat GM. Teaching and learning medical ethics and law in UK medical schools. Clinical Ethics 2010; 5(3): 156-158.

63. Fenwick A. Medical ethics and law: assessing the core curriculum. Journal of Medical Ethics 2014; 40(10): 719-720.

64. Burling SJ, Lumley JSP, McCarthy LSL, Mytton JA, Nolan JA, Sissou P, et al. Review of the teaching of medical ethics in London medical schools. Journal of Medical Ethics 1990; 16(4): 206-209.

65. Mattick K, Bligh J. Undergraduate ethics teaching: revisiting the Consensus Statement. Medical Education 2006; 40(4): 329-332.

66. Johnston C, Mok J. How medical students learn ethics: an online log of their learning experiences. Journal of Medical Ethics 2015; 41(10): 854-858.

67. Brooks L, Bell D. Teaching, learning and assessment of medical ethics at the UK medical schools. Journal of Medical Ethics 2017; 43(9): 606-612.

68. Ravindran GD, Kalam T, Lewin S, Pais P. Teaching medical ethics in a medical college in India. National Medical Journal of India 1997; 10(6): 288-289.

69. D’Souza RF, Mathew M, D’Souza DSJ, Palatty P. Novel horizontal and vertical integrated bioethics curriculum for medical courses. Medical Teacher [Internet] 2018; 40(6): 573-577. DOI: https://doi.org/10.1080/0142159X.2018.1442921

70. Oliveira AM de. Bioetica e as diretrizes curriculares nacionais do curso de medicina. Revista Brasileira de Saude Materno Infantil 2010; 10(SUPPL. 2): 303-309.

71. Chin JJL, Voo TC, Abdul Karim S, Chan YH, Campbell A V. Evaluating the effects of an integrated medical ethics curriculum on first-year students. Annals of the Academy of Medicine Singapore 2011; 40(1): 4-18.

72. Sherer R, Dong H, Cong Y, Wan J, Chen H, Wang Y, et al. Medical ethics education in china: Lessons from three schools. Education for Health: Change in Learning and Practice 2017; 30(1): 35-43.

73. Brunger F. Guidelines for Teaching Cross-Cultural Clinical Ethics: Critiquing Ideology and Confronting Power in the Service of a Principles-Based Pedagogy. Journal of Bioethical Inquiry 2016; 13(1): 117-132.

74. Okoye O, Nwachukwu D, Maduka-Okafor FC. Must we remain blind to undergraduate medical ethics education in Africa? A cross-sectional study of Nigerian medical students. BMC Medical Ethics 2017; 18(1): 1-8.

75. Oldroyd C, Fialova L. Ethics teaching on "Beginning of Life" issues in UK medical schools. Journal of Medical Ethics 2014; 40(12): 849-853.

76. Alkaabba A, Hussein GMA. Democratization of Medical Education is needed to effective teaching of Bioethics. Lebanese Medical Journal 2011; 59(1): 33-36.

77. Ghias K, Ali SK, Khan KS, Khan R, Khan MM, Farooqui A, et al. How we developed a bioethics theme in an undergraduate medical curriculum. Medical Teacher 2011; 33(12): 974-977.

78. Babapulle CJ. Teaching of medical ethics in Sri Lanka. Medical Education 1992; 26(3): 185-189.

79. Tweel WT. Five ethical doctrines for medical education. Journal of medical ethics 1982; 8(1): 37-39.

80. Hafferty FW, Franks R. The hidden curriculum, ethics teaching, and the Structure of Medical Education. Academic Medicine 1994: 861-871. 
81. Cowley C. The dangers of medical ethics. Journal of Medical Ethics 2005; 31(12): 739-742.

82. Peeling RW, Saxena A. Books \& Electronic Media. Bulletin of the World Health Organization 2006; 84(February): 159 160.

83. Tsai DFC. The WMA Medical Ethics Manual. Journal of Medical Ethics 2006; 32(3): 163.

84. UNESCO. Bioethics Core Curriculum Section 1: Syllabus. Ethics education programme. Bioethics Core Curriculum [Internet]. Available from: www.\%0Aunesco.org/shs/ethics/eep\%0A

85. Gomes AP, Rego S. Transformation of Medical Education: Can a New Physician be Trained based on Changes in the Teaching-Learning Method? Revista Brasileira de Educação Médica 2011; 35(4): 557-566.

86. Machado CDB, Wuo A, Heinzle M. Brazilian Medical Education: a Historical Analysis of Academic and Pedagogical Education. Revista Brasileira de Educação médica 2018; 42(4): 66-73.

87. Schauber SK, Hecht M, Nouns ZM, Kuhlmey A, Dettmer S. The role of environmental and individual characteristics in the development of student achievement: a comparison between a traditional and a problem- based-learning curriculum. Adv in Health Sci Educ 2015; 20, 1033-1052. DOI: https://doi.org/10.1007/s10459-015-9584-2.

88. Raimondi GA, Tourinho FSV, Souza FGR, Pereira DVR, Oliveira DOPS de, Rosa LM. Análise Crítica das DCN à Luz das Diversidades: Educaçáo Médica e Pandemia da Covid-19. Revista Brasileira de Educação Médica 2020; 44(suppl 1): $1-8$.

89. Liddle SNHJPSDGLCRCC. Do medical courses adequately prepare interns for safe and effective prescribing in New South Wales public hospitals? Internal Medicine Journal 2009; 39(7): 428-434.

90. Cave J, Goldacre M, Lambert T, Woolf K, Jones A, Dacre J. Newly qualified doctors' views about whether their medical school had trained them well: questionnaire surveys. BMC Med Educ 2007; 7: 38. DOI: https://doi.org/10.1186/14726920-7-38

91. Lorrie A. Langdale, MD, Doug Schaad, PhD, Joyce Wipf, MD, Susan Marshall M, Louis Vontver, MD, and Craig S. Scott P. Preparing Graduates for the First Year of Residency: Are Medical Schools Meeting the Need? Academic Medicine 2003; 78: 39-44.

92. Armstrong EG, Mackey M, Spear SJ. Medical Education as a Process Management Problem. Academic Medicine 2004; 79: 721-728.

93. Ferguson GR, Bacila IA, Swamy M. Does current provision of undergraduate education prepare UK medical students in ENT? A systematic literature review. BMJ Open 2016; 6: e010054. DOI:10.1136/bmjopen-2015-010054

94. Muller JH, Jain S, Loeser H, Irby DM. Lessons learned about integrating a medical school curriculum: perceptions of students, faculty and curriculum leaders. Medical Education 2008; 42: 778-785.

95. Birden H, Glass N, Wilson I, Harrison M, Usherwood T, Nass D. Teaching professionalism in medical education: A Best Evidence Medical Education (BEME) systematic review. BEME Guide No 25. Medical Teacher 2013; 35: e12521266.

96. Soleymani Lehmann L, Snyder Sulmasy L, Desai S. ACP Ethics, Professionalism and Human Rights Committee. Hidden curricula, ethics, and professionalism: Optimizing clinical learning environments in becoming and being a physician: A position paper of the American college of physicians. Annals of Internal Medicine 2018; 168(7): 506-508.

97. Carrese JA, Malek J, Watson K, Lehmann LS, Green MJ, Mccullough LB, et al. The Essential Role of Medical Ethics Education in Achieving Professionalism: The Romanell Report. Academic Medicine 2015; 90(6): 744-752.

98. Lawrence C, Mhlaba T, Stewart KA, Moletsane R, Gaede B, Moshabela M. The Hidden Curricula of Medical Education: A Scoping Review. Academic Medicine 2018; 93(4): 648-656.

99. Frenk J, Chen L, Bhutta ZA, Cohen J, Crisp N, Evans T, et al. Health Professionals for a New Century: Transforming Education to Strengthen Health Systems in an Interdependent World. The Lancet 2010; 376: 1923-1958.

100. Moura ACA de, Mariano L de Á, Gottems LBD, Bolognani CV, Fernandes SES, Bittencourt RJ. Teaching-Learning Strategies for Humanistic, C and Ethical Undergraduate Medical Training: a Systematic Review. Revista Brasileira de Educação Médica 2020; 44(3): e076.

101. Lipworth W, Kerridge I, Little M, Gordon J, Markham P. Meaning and value in medical school curricula. Journal of Evaluation in Clinical Practice 2012; 18(5): 1027-1035.

102. Alkabba AF, Hussein GM, Kasule OH, Jarallah J, Alrukban M, Alrashid A. Teaching and evaluation methods of medical ethics in the Saudi public medical colleges: Cross-sectional questionnaire study. BMC Medical Education 2013; 13(1): 4-11.

Received: April 5, 2021

Accepted: April 15, 2021 